\title{
Determinants of Rural Households Livelihood Diversification Strategies in Kuarit District, West Gojjam Zone of, Amhara Region, Ethiopia
}

\author{
Melese Abawa Tizazu, ${ }^{1, *}$, Getaneh Mihret Ayele ${ }^{2}$, Gemechu Shale Ogato ${ }^{3}$ \\ ${ }^{1}$ Department of Agricultural Economics, Collage of Agriculture and Natural Resource, Jinka University, Jinka, Ethiopia \\ ${ }^{2}$ Department of Economics, College of Business and Economics, Bahir-Dar University, Bahir-Dar, Ethiopia \\ ${ }^{3}$ Departments of Rural Development and Agricultural Extension, Ambo University, Ambo, Ethiopia \\ Email address: \\ meleseabawa192@gmail.com(M. A. Tizazu),getanehmihret@yahoo.com(G. M. Ayele), gemechushale2005@yahoo.com(G. S. Ogato) \\ ${ }^{*}$ Corresponding author
}

\section{To cite this article:}

Melese Abawa Tizazu, Getaneh Mihret Ayele, Gemechu Shale Ogato. Determinants of Rural Households Livelihood Diversification Strategies in Kuarit District, West Gojjam Zone of, Amhara Region, Ethiopia. International Journal of Economic Behavior and Organization. Vol. 6, No. 3, 2018, pp. 61-68. doi: 10.11648/j.ijebo.20180603.11

Received: November 10, 2018; Accepted: December 7, 2018; Published: January 2, 2019

\begin{abstract}
This study examined the existing livelihood strategies and its determinant in Kuarit District, West Gojjam Zone, Amhara Region, Ethiopia. The study used primary data collected from 144 sampled respondents using semi-structured household survey questionnaire, focus group discussion, key informant interview and personal observations. A Multistage sampling technique was used to select kuarit district, the study villages and sample respondents. Descriptive statistics results revealed that more than half of sampled respondents $(57.6 \%)$ combine on-farm activity with other non-farm and off-farm activities. Inferential statistics results using ANOVA and Chi-square tests showed that there is significant mean difference between groups of livelihood strategies in terms of dependency ratio of the household, total annual income, distance from the nearest market, total livestock ownership of the household, access to credit service and educational statues of the household head. Multinomial logit model results showed that access to credit service, total annual income and total family size have positive effect on choices of livelihood diversification strategies; while market distance, age, total livestock holding and dependency ratio of the household head have negative effect on choices of livelihood diversification strategies. Thus, policymakers should give due attention and incorporate those negative and positive factors in planning rural development strategies and polices.
\end{abstract}

Keywords: Livelihood Diversification Strategies, Multinomial Logit, Rural Households, Kuarit

\section{Introduction}

Livelihood diversification is an active and changing phenomena taking place in rural areas. It is "the process by which rural households construct an increasingly diverse portfolio of activities and assets in order to survive and improve their standard of living". It may also refer to an attempt undertaken by an individual or a household to find new ways of survival and a risk management strategy; both risk mitigation in anticipation of shock and coping after actual shocks [1-2]. Regardless of slight change in mode of livelihood strategies, agriculture continues to play significant role in the livelihood of the majority of rural households in Ethiopia. The sector contributes more than $42 \%$ of the gross domestic product of the country (GDP) of the country, and provides livelihood to about $85 \%$ of the population [3].

Further, to this agriculture is a main source of raw materials for the manufacturing sector of the country. However, there is growing evidence that agriculture sector alone has failed to feed rapidly growing population of the country. For instance, [4 cited in 5], notified that 'more than 27 million people become food insecure and total population of 18.1 million people require food assistance in 2016 due climate change and 2015 El Niño drought derived problems'. Thus, the expectation that achieving the goal of reducing 
poverty only through increasing agricultural productivity without partake in to non/off-farm activities could not be successful in sub-Sahara African countries like Ethiopia [6].

Currently, there is a growing evidence that rural households in rural Ethiopia are participated in diverse livelihood strategies away from purely crop and livestock production towards non-farm and off-farm activities that are undertaken to broaden and generate additional income for survival and cope with different livelihood shocks, trends, and seasonality associated with agricultural production [6-8]. However, their participation is determined by various contextual factors such as Agro-ecology, educational level of the household, land size, livestock ownership, total income, family size, access to credit service, remittance receiving, dependency ratio [9-11].

Though there are many livelihood studies done in the world and Ethiopia, few scientific works [11-13], had been done in Amhara region in relation to factors that could influence the choice of livelihood diversification strategies and they were not able to give enough information on exiting livelihood strategies and its determinant. This could be due to the disparity in the effect of factors affecting livelihood diversification strategies at different locations with different livelihood outcomes [12]. To this end, none of these empirical studies are conducted in kuarit district. Hence, the intent of this study is to identify the existing livelihood strategies and its determinant in the study area. with the hope of local, regional, national, and international contribution for addressing knowledge and development gaps.

\section{Methodology}

\subsection{Description of Study Area}

Kuarit is one of the 105 districts in Amhara Region. It is $560 \mathrm{~km}$ to the north of the capital city, Addis Ababa. The district is divided into 30 villages ( 2 urban villages and 28 rural villages). It is part of the West Gojam Zone bordered on the southwest by the JabiTehnan, on the west by Sekela, on the north by Adet, on the east by the Misraq Gojjam Zone on the north-east by GonchKolela and on the Southeast by DegaDamot (See figure 1). The major town the district is Gebeze Mariam. It is the source of Birr River that contributes to the Blue Nile River. In the study district there are 28 villages from these three rural villages namely Kuarit Enchillala, Asheti Talia and Genet Delndi were the study sites. The altitude of the district ranges between 1920-3550 masl with mean annual rain fall of $1700 \mathrm{~mm}-2000 \mathrm{~mm}$ [14].



Source: Designed by expert based on Ethiopia GIS, 2017

Figure 1. Location of the study area. 


\subsection{Sampling Techniques and Procedures}

In this study, multi-stage sampling procedure is employed to select sample households. In the first stage, out of the sixteen districts in the Zone, kuaritis selected purposively because rural households in the study area participate in livelihood strategies. At the second stage out of twenty eight rural villages' three villages namely Asheti-Lebagedel, KuritEnechilala and Genet Delandi were purposively selected as the researcher is interested to assess the determinants of livelihood strategies in the context of low land agro-ecology. At the third stage, total sample respondents of 144 were selected by using simple random sampling technique, and proportion to population size. The sample size was determined based on Yamane (1967) formula [15].

\subsection{Methods of Data Collection}

Both the qualitative and quantitative method of data collection is employed to address the basic objectives of this study. The primary data were collected through household survey questionnaire among 144 randomly selected sample household respondents. In addition, 4 focus group discussions, 10 key informant interviews and field observations were employed in order to explore and fully describe the existing livelihood diversification strategies in the study area. Moreover, prior to actual survey, the questioners were pre tested on non-sample respondents for consistency, clarity, and to check its validity and reliability as well as get the intended data.

\subsection{Methods of Data Analysis}

Depending on the natures of the data and specific objective of the study, both descriptive and inferential statistics along with multinomial logit model were employed to analyse the data. Specifically, multinomial logit model were employed to analyse the determinants of rural household's livelihood diversification strategies. The data analysis was conducted using STATA 13.

\subsection{Multinomial Logistic Model Specification}

One of the underlying motivations for household's alternative livelihood strategies is to maximize utility from expected earnings of particular strategy [9]. The model determining the choice of the probability that the $i^{\text {th }}$ household chooses alternative livelihood strategy set $\boldsymbol{a}$, is the multinomial logit (MNL) if the sets are not ordered [16]. The model exhibits a superior ability to predict livelihood diversification and picking up the differences between the livelihoods strategies of rural households [17-18]. However, for one to use MNL the households have to be clustered into different categories and the basic assumption is that households in a given category participate in some given livelihood strategies, and hence, cannot participate in strategies that are chosen by households in another category [19]. Following [20], the maximum utility model of households from different livelihood strategies can be specified as follows:

Let $U i j$ denotes the utility that the household $i$ gets from choosing alternative activity $\mathrm{j}$ and.

$$
U_{i j}=x_{i j} \beta_{j}+€_{i j}
$$

Where, $\beta_{j}$ is the coefficient of covariates which varies across alternatives, $x_{i j}$ - is the covariates which remains constant across alternatives; and $\epsilon_{i j}$-is a random disturbance term, and unobserved attributes of alternatives.

For an outcome variable with $J$ categories, let the $j^{\text {th }}$ livelihood strategy that the $i^{\text {th }}$ household chooses to maximize its utility could take the value 1 if the $i^{\text {th }}$ household choose $j^{\text {th }}$ livelihood strategy and 0 otherwise. The probability, that a household with characteristics $x$ choose livelihood strategy $j,(P i j)$ is modeled as:

$$
p i j=\frac{\exp (x i \beta j)}{\sum_{j}^{j}=0 \exp (x i \beta j)}, j=0
$$

With the requirement of $\sum_{j=0}^{j} p i j=1$ for any $i$ Where: $P i j=$ probability representing the $i^{\text {th }}$ respondent's chance of falling into category $j, X=$ Predictors of response probabilities, $\beta_{j}=$ Covariate effects specific to $\mathrm{j}^{\text {th }}$ response category with the first category as the reference. Then, the appropriate normalization that removes indeterminacy in the model is to assume that $\beta_{1}=0$ (this arises because probabilities sum to 1 , so only $\mathrm{J}$ parameter vectors are needed to determine the $J+1$ probability), [20] so that $\exp \left(X_{i} \beta_{1}\right)=1$, implying that the generalized equation (2) above is equivalent to:

$$
\begin{array}{r}
p i j=\exp \frac{x i \beta j}{1+\sum_{j}^{3}=1}, \text { for } j=(1,2,3) \text { and } \\
\text { pi } 1=\frac{1}{1+\sum_{j}^{3}=1 \exp (x i \beta j)}
\end{array}
$$

Similar to binary logit model it implies that we can compute $J$ log-odds ratios which are specified as;

$$
\ln \left[\frac{p i j}{p i j}\right]=x^{\prime}[\beta j-\beta J]=x^{\prime} \beta j \text {, if } J=0
$$

Table 1. Definition of model variables.

\begin{tabular}{ll}
\hline Dependent variable & \\
\hline Choice of livelihood diversification strategies & Descriptions of Livelihood diversification Strategies \\
\hline $\mathrm{Y}=0$, On-Farm only & Agriculture alone \\
$\mathrm{Y}=1$, On-Farm+Off-Farm & Combination of agriculture and off-farm \\
$\mathrm{Y}=2$, On-Farm+Non-Farm & Combination of agriculture and non-farm \\
$\mathrm{Y}=3$, On-Farm+Off-Farm+Non-Farm & Combination of agriculture off-farm and non-farm \\
\hline
\end{tabular}




\begin{tabular}{lllll}
\hline \multicolumn{2}{l}{ Independent variables } & & & Nature \\
\hline No & Variable code & Variable name & Continuous & - \\
\hline 1 & AGEHH & Age of the household head & Dummy & - \\
2 & SEXHH & Sex of the household head & Dummy & + \\
3 & EDUCHH & Education statues of the household head & Continuous & + \\
4 & FAMLSIZ & Total family size of the household & Continuous & - \\
5 & DPRHH & Dependency ratio of the household & Continuous & - \\
6 & MKTDST & Distance from the input output market & Continuous & - \\
7 & LNDSZ & Total land size in hectares & Continuous & - \\
8 & TLU & Total livestock owned by household in TLU & Dummy & + \\
9 & CRDIT & Access to credit service & Dummy & + \\
10 & ACCEXTN & Access to extension service & Continuous & + \\
11 & INCOME & Total income of the household & & \\
\hline
\end{tabular}

\section{Results and Discussion}

\subsection{Rural Households Livelihood Strategies}

In the study area, there are four groups of livelihood diversification strategies that rural households have adopted to achieve their livelihood outcomes. Figure 2 below shows the category of the different livelihood strategies that households pursue in the study area. The survey result indicated that On-farm(agriculture only - crop and livestock production) livelihood strategy is the most commonly used strategy, in 1 which about $42.36 \%$ sample respondents are engaged in, followed by On-farm+Non-farm livelihood strategy (about $21.53 \%$ of the household are engaged in). Moreover, about $19.44 \%$ of the households combined Onfarm activity with Off-farm activity as their livelihood strategy. To this end, $16.67 \%$ of the household respondents were engaged in combination of On-farm+Off-farm+Nonfarmlivelihood strategy to derive their livelihood outcomes.

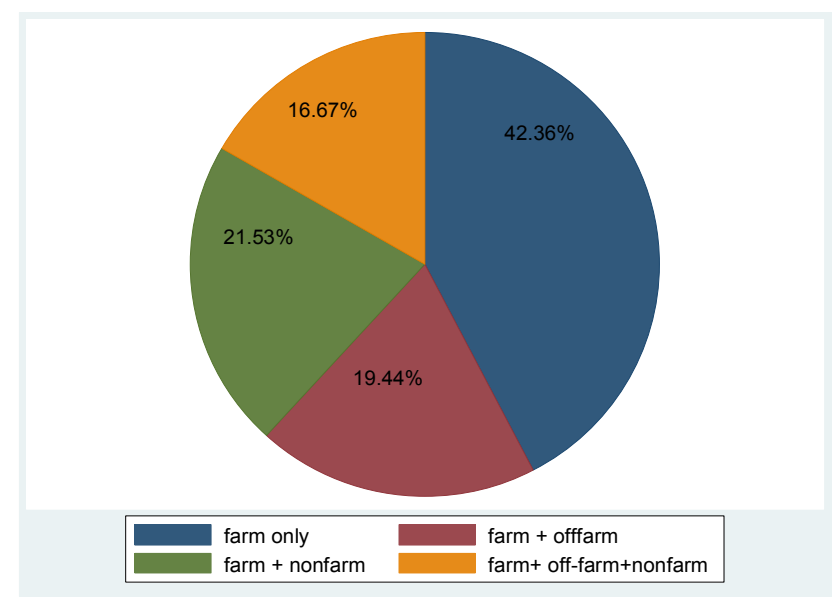

Figure 2. Distribution of sample households by livelihood diversification strategies.

1 On-farm refers to are those agricultural activities mainly of crop production, cattle rising and poultry production. Off-farm activities-are those agricultural activities takes place outside households own farm area (daily wage laborer, charcoal selling, livestock trading etc). Non-farm activities are non-agricultural activities takes place outside the agricultural sector.

\subsection{Comparison of Livelihood Diversification Strategies}

The study conducted analysis of variance (ANOVA) and chi-square test to make sure the presence or absence of difference between the livelihood strategies of the households. The mean values of continuous variables in all livelihood categories were compared using ANOVA. It showed the presence of a significant mean difference between rural households falling in the four livelihood strategies in terms of total annual cash income, distance from the nearest market, dependency ratio of the household head, and total livestock ownership of the household head. The study results showed that those farmers who use the combination of on-farm, off-farm and non-farm activities as their livelihood had relatively better total annual cash income than the others. Their mean value of total annual cash income was Birr 16,161.67, while it was Birr 9561.2, 6512.5 and 6494 for those households relying on farm and non-farm, farm and off-farm and farm alone to drive their livelihood respectively (see Table 2). The average time taken from the nearest market were 1.64, 0.9, 0.92 and 0.7 for the households engaged in ON-farm only, ON+OFF, $\mathrm{ON}+\mathrm{NF}$, and $\mathrm{ON}+\mathrm{OFF}+\mathrm{NF}$, respectively. The result depicts that those households nearest to the input-output market are participated in off/non-farm activities (See Table 2). Moreover, there average livestock ownership of those households who were engaged in $\mathrm{ON}-$ farm only, $\mathrm{ON}+\mathrm{OFF}$, $\mathrm{ON}+\mathrm{NF}$, and $\mathrm{ON}+\mathrm{OFF}+\mathrm{NF}$ were $4.63,3.68,4$, and 3.52 respectively. This indicates that, on average those households who have owned less number of livestock's were engaged in different non/off-farm activity as compared those households who have owned more number of livestock (See Table 2).

On the other hand, a chi-square test indicated the existence of statistically significant difference between the four strategies in terms of 4 discrete variables. More specifically, the test revealed that there was a significant difference between the livelihood groups in terms of access to credit service and educational statues of the household head at $1 \%$ probability level (Table 3). 


\section{Interpretation of significant variables}

Age of household head (AgeHH): As expected, this was found significantly and negatively influence households' choice of On-Farm+Off-Farm, On-Farm+Non-Farm OnFarm+Off-Farm+Non-Farm livelihood strategies at 1\%, 5\% and $10 \%$ significance level, respectively. Given all other variables in the model held constant, a one year increase in age of the household will decrease household's choices of On-Farm+Off-Farm, On-Farm+Non-Farm, On-Farm+OffFarm+Non-Farm livelihood strategies by $1.3 \%, 2.1 \%$, and $0.1 \%$ respectively relative to the base on-farm only. This implies that farmers, whose age is relatively younger, could be pushed to engage more in off-farm and non-farm activities than agriculture alone.

The possible reason could be younger households cannot get enough land to support their livelihood compared to the older farm households. This result is agree with previous studies by [21] and [22] but contradicts with [23].

Total livestock holding (Tlu): As hypothesized, livestock holding of the household head was negatively and significantly affected household's choice On-Farm+OffFarm, and On-Farm+Off-Farm+Non-Farm livelihood strategies at $10 \%$ and $1 \%$ significance level. This is because of in the study area, majority of farm households depend on livestock production for their farm income. The negative association between livelihood diversification and number of TLU implies that herd size creates better opportunity to earn more income from livestock production. The income generated from livestock helps farmers to fulfill family requirement including food. Hence, households who can get the required amount of food from livestock may not engage in another income generating activities unless their objective is to increase their asset holding. Conversely, households with less number of livestock try to diversify their income portfolio by participating in non-farm and off-farm activities and this accelerates the rate of diversification. Ceteris paribus, a $1 \%$ increase in tropical livestock unit will decrease the likelihood of diversifying in to on-farm + off-farm and on-farm +off-farm + non-farm livelihood strategy by $2.8 \%$ and $3.49 \%$, respectively for households with more livestock number in TLU compared to the base category of on-farm alone. This result is in line with [24].

Access to credit service (Crdit): As expected, access to credit has a significant and positive association with the likelihood of choosing $\mathrm{ON}+\mathrm{OFF}, \mathrm{ON}+\mathrm{NF}, \mathrm{ON}+\mathrm{OFF}+\mathrm{NF}$ livelihood diversification strategy at $10 \%$ probability level. Keeping all other variables in the model held constant, the likelihood of the choice of $\mathrm{ON}+\mathrm{OFF}, \mathrm{ON}+\mathrm{NF}, \mathrm{ON}+\mathrm{OFF}+\mathrm{NF}$ livelihood diversification strategy for those households who have access to credit service will increase by $8.4 \%, 24 \%$ and $12.6 \%$ respectively relative to the base agriculture only. This is due to the reason that households who have limited land size can diversify their livelihood if they have easy access to credit service. This result is congruent with [7] and contradicts with [9].

Distance from the nearest market (Mktdst): As expected, has a negative and statistically significant effect on households' choice of ON-Farm + OFF-Farm, ON-Farm + NON-Farm, ON-Farm + OFF-Farm + NON-Farm livelihood diversification strategies. Keeping all other variables constant, $1 \%$ increases in the time taken from the nearby market distance decreases likelihood of household head simultaneous choice of ON-Farm + OFF-Farm, ON-Farm + NON-Farm, and ON-Farm + OFF-Farm + NON-Farm livelihood diversification strategies by $20.7 \%, 16.8 \%$, and $10 \%$ respectively relative to the base agriculture. The possible reason for the result might be that householdsfar from the market center will have no easy and quick physical access to the market to transport amount produced. The result is in line with the findings of [21].

Total annual income (income): The income variables have positive and significant influence on household's choice of $\mathrm{ON}+\mathrm{OFF}+\mathrm{NF}$ livelihood diversification strategy at $1 \%$ significance level. This implies that households with large total annual income are more likely to diversify the livelihood strategies into off-farm and non-farm livelihood strategies. This result shows that those farmers with low income are less likely to diversify livelihood strategies into agriculture plus off-farm activities plus non-farm livelihood strategies. Keeping the effect of all other variables in the model constant, the marginal effect result reveals that the probability of a household diversifying into combination of $\mathrm{ON}+\mathrm{OFF}+\mathrm{NF}$ livelihood activity increases by $0.0012 \%$ for those farm households with more level of income relative to the base agriculture only (Table 4). The possible reason is that those farmers who have adequate income sources can overcome financial constraints to engage alternative livelihood strategies. The result is in line with [10].

Dependency ratio of the household (Dprhh): As expected, this variable has a significant and negativeassociation with choice decision of the household to diversify in $\mathrm{AG}+\mathrm{NF}$ livelihood strategy at 5\% level. Keeping all other variables in the model held constant, when one number of the dependent family member added to the household member, chance of diversifying livelihood in to agriculture plus non-farm livelihood diversification strategy will decrease by $9.6 \%$ relative to the base agriculture only. This finding is in consistent with [9] and [25].

Family size (Famsizh): in line with previous expectation, this variable has positive and significant relation to choice of $\mathrm{ON}$ Farm + NON-Farm livelihood diversification strategy at $<10 \%$ probability level. This might be due to the relation between larger family size and household labor or corresponding higher demand for food in the household [9]. The marginal effect result reveals that, as the number of total family size increase by one, the probability of engagement in non-farm increases by $5.9 \%$ relative to the base agriculture only. In other words, additional family member decreases the odds to work only on farming. This finding is similar to that of [7].

\section{Conclusion and Recommendation}

\subsection{Conclusion}

This study was aimed to identify the existing livelihood 
diversification strategies and its determinants. The data were collected from both from primary and secondary sources. The primary data were collected from individual interview using semi-structured household survey questionnaire from 144 randomly selected sample respondents. Secondary data were obtained from different unpublished and published sources. Data analysis was made using descriptive statistics, inferential statistics and econometric analysis. Since the determinants of rural households livelihood strategies can vary from one geographical area to another geographical area, across time and individuals to come up with the final result and implication of the study, multinomial logit model was employed for analyzing the data.

From the descriptive statistics, the existing livelihood diversification strategies that were persuaded by rural households in the study area were on-farm only $(42.36 \%)$, on-farm plus off-farm (19.44\%), on-farm plus non-farm $(21.53 \%)$ and on-farm plus off-farm plus non-farm (16.67\%). The inferential statistic result confirmed that there was a significance mean difference between groups of livelihood strategies of rural households of the study area in terms of dependency ratio of the household, total annual cash income, distance from the nearest market, total livestock ownership of the household, access to credit service and educational level of the household head.

The multinomial logistic regression result depicts that distance from the nearest market, age of the household head, total livestock holding and access to credit service have a significant effect on choice of combination of On-farm+Offfarm livelihood diversification strategy as compared to the base category on-farm alone. The result also shows that distance from the nearest market, age of the household head, dependency ratio of the household head, family size of the household head and access to credit service significantly affect choice of combination of On-farm+Non-farm livelihood diversification strategy. Further, distance from the nearest market, total annual income of the household head, age of the household head, total livestock holding of the household head, and access to credit service significantly affect choice of combination of On-farm+Off-farm+Nonfarm livelihood diversification strategy.

\subsection{Recommendation}

Based on the finding of this study, policies as well as actions directed towards improving the livelihood of the rural households in the study area should focus on:

Expand infrastructure and input and output market in the rural area and fill the market information gabs

Increase the credit access and strength the institutional arrangement so as to improve the livelihood of rural households.

Solve financial problems through increasing and strengthening financial institution and promoting better income generating options.

Expand and strengthening the agricultural extension service for rural households so as to create a diversified livelihood activities and improve the livelihood of the rural households.

\section{References}

[1] Ellis, F. (2000). The Determinants of Rural Livelihood Diversification in Developing Countries. Journal of Agricultural Economics, 51(2): 289-302. USA.

[2] Khatun, D. and Roy, B. C. (2012). Rural Livelihood Diversification in West Bengal: Determinants and Constraints. 25(1):115-124. Thesis submitted to Visva-Bharati University, Sriniketan - 731 236, West Bengal.

[3] CSA (Central Statistical Agency). (2015). The Federal Democratic Republic of Ethiopia Statistical Agency. Addis Ababa, Ethiopia.

[4] Catley et al., (2016), "USAID/Ethiopia Agriculture Knowledge, Learning, Documentation and Policy Project". No. 663-13-000006: implemented by the Feinstein International Center, Friedman School of Nutrition Science and Policy, Tufts University.

[5] Abdulahi, A. (2017). "Food Security Situation in Ethiopia: A Review Study. International Journal of Health Economics and Policy". Vol. 2, No. 3, 2017, pp. 86-96. doi: 10.11648/j.hep.20170203.11.

[6] Emanuel, E. (2011). Rural Livelihood Diversification and Agricultural household welfare in Ghana. J. Develop. Agric. Econ. 3(7):325-334.

[7] Anshiso, D., \& Shiferaw, M. (2016). Determinants of Rural Livelihood Diversification: The Case of Rural Households in Lemmo District, Hadiyya Zone of Southern Ethiopia. Journal of Economics and Sustainable Development, 7(5), 32-39. retrieved from www.iiste.org.

[8] Demissie A., \& Legesse B. (2013). Determinants of income diversification among rural households: The case of smallholder farmers in Fedis district, Eastern Hararghe zone, Ethiopia. Journal of Development and Agricultural Economics 5(3):120-128.

[9] Eneyew A., \& Bekele W. (2012). Determinants of Livelihood Strategies in Wolaita, Southern Ethiopia. A research journal on Agricultural Research and Reviews Vol. 1(5):153-161. Available on line at http://www.wupeckerresearchjournals.org/arr

[10] Gecho, Y., Ayele, G., Lemma, T.,\& Alemu, D.(2014). Rural Household Livelihood Strategies: Options and Determinants in the Case of Wolaita Zone, Southern Ethiopia. Social $\begin{array}{lllll}\text { Sciences. } & \text { Vol. 3(3). pp. 92-104. doi: }\end{array}$ 10.11648/j.ss.20140303.15.

[11] Yizengaw, Y. S., Eric, N. O., \& Byene, F. (2015). Determinants of livelihood diversification strategies: The case of smallholder rural farm households in Debre Elias Woreda, East Gojjam Zone, Ethiopia. African Journal of Agricultural Research, Vol. 10(19). PP. 1998-2013. Doi: 10.5897/AJAR2014.9192.

[12] Temesgen, D. Tilahun, S. Yousuf, J. (2016). Analysis of Livelihood Strategy Determinates Among Different Wealth Categories of Rural Households: A Case from Amhara Region of Ethiopia. Journal on Developing Country Studies Vol.6, No.2, 2016. Available online at www.iiste.org. 
[13] Berlie, B. A. (2016). Non-Farm And Off-Farm activities in Achieving Livelihood Security in Amhara Region: Case study of Lay Gayint District. Journal of Agriculture and Environmental Sciences. Vol.1(2).

[14] Kuarit District Office of Agriculture and Rural Development, (2014). Kuarit District Agriculture and Rural Development Office General Agricultural Activities Report.

[15] Yamane, T. (1967). Statistics: An Introductory Analysis, 2nd Ed., New York: Harper and Row.

[16] Warren, F. Kuhfeld. (2010). MR-2010G- Multinomial Logit Models.

[17] Keane, M. P. (1992). A Note on Identification in the Multinomial Probit Model. Journal of Business and Economic Statistics, Vol. 10, pp. 193-200.

[18] Chan, Y. H. (2005). Basic statistics for doctors, multinomial logistic regression, Singapore.

[19] Brown, D. R., Stephens, E. C., Ouma, J. O., Murithi, F. M., \& Barrette, C.B. (2006). Livelihood Strategies in the Rural Kenyan Highland.
[20] Greene, H. W. (2003). Econometric Analysis: Fourth Edition. New York University Macmillan Publishing Company.

[21] Abdissa, N. (2011). Determinants of Rural Livelihood Strategies: The Case of Rural Kebeles of Dire Dawa Administration. MSc. Thesis Submited to the School of Gradute Studies, Haramaya University. Haramaya, Ethiopia.

[22] Lemi, A. (2005). The Dynamics of Livelihood Diversification in Ethiopia Revisited: Evidence from Panel Data, Department of Economics University of Massachusetts, Boston.

[23] Gagabo, T. (2014). Analyzing the determinants and the effects of income diversification in rural Ethiopia. International social science.

[24] Negeri, B., \& Demissie, G.(2017). Livelihood Diversification: Strategies, Determinants and Challenges for Pastoral and Agro-Pastoral Communities of Bale Zone, Ethiopia. American Journal of Environmental and Geoscience, Vol.1, Issue 1, pp. 19-28.

[25] Dessalegn, M., \& Ashagrie, E. (2016). Determinants of Rural Household Livelihood Diversification Strategy in South Gondar Zone, Ethiopia. Journal of Agricultural Economics, Extension and Rural Development: ISSN-2360-798X, Vol. 4(8): pp, 548-560. 